\title{
Studying and Working-Hurdle \\ or Springboard? Widening Access \\ to Higher Education for Working \\ Students in Malta
}

\author{
Christine Scholz Fenech and Milosh Raykov
}

\section{Introduction}

Higher education has a significant influence on all members of a society as well as on the overall national social and economic development. The provision of equitable access to higher education is not only imperative for attaining inclusive societies but also central to fostering economic development and harnessing the creative potential of people (Bergan 2005; Zgaga 2005; Orr 2012). This has also been acknowledged by policymakers (Brooks 2017), which in the Bologna Process stressed:

\begin{abstract}
the societal aspiration that the student body entering, participating in and completing higher education at all levels should reflect the diversity of our populations. We reaffirm the importance of students being able to complete their studies without obstacles related to their social and economic background. We therefore continue our efforts to provide adequate student services, create more flexible learning pathways into and within higher education, and to widen participation at all levels on the basis of equal opportunity. (London Communiqué 2007, p. 5)
\end{abstract}

The impact of higher education on economic development is also the focus of the Lisbon Strategy, which in 2000 established the goal of becoming "the most competitive and dynamic knowledge-based economy in the world, capable of sustainable economic growth with more and better jobs and greater social cohesion" (European Council 2000, p. 3). More recently, it was emphasized in the EU 2020 strategy seeking to increase the educational attainment among 30-34-year-olds to

C. Scholz Fenech $(\bowtie)$

National Commission for Further and Higher Education (NCFHE),

San Gwann, Malta

e-mail: christine.scholz-fenech@gov.mt

M. Raykov

Faculty of Education, University of Malta, Msida, Malta

e-mail: milosh.raykov@um.edu.mt

(C) The Author(s) 2018

A. Curaj et al. (eds.), European Higher Education Area: The Impact of Past and Future Policies, https://doi.org/10.1007/978-3-319-77407-7_16 
40\% by 2020 (European Commission 2010). Through the recent skills agenda, the European Commission also emphasizes the importance of the higher education sector to respond to labour market needs (European Commission 2016).

Thus, the importance of widening access to higher education is not only a question of ensuring an inclusive society but also a response to labour market demands. Orr (2010), with reference to Kouckŷ and CEDEFOP, has argued that maintaining current graduate rates will not be sufficient to meet the market demand for highly skilled labour. Increasing attainment levels may not be realised only by increasing the share of post-secondary school graduates continuing in higher education but also through attracting and re-integrating those who did not continue their education. Thus, meeting the labour market demand requires catering to the needs of a more diversified student population. As Beerkens et al. (2011) argues, this is particularly the case for strong and rapidly expanding economies with a shortage of skilled workers that incentivise an early entry into the labour market, and the likelihood that those who took up employment would be hesitant to give it up to take on full-time studies.

Malta is an example of such a situation. As Auers et al. (2007) argue in the case of Latvia, Malta faced a triple challenge. First, as a young independent nation-state, it remained dependent on its former colony economically well up to 1990 (Vella 1994) through a low-paid and low-skilled export-driven manufacturing sector restricting its potential for self-sustained growth. Second, as a result, it experienced an expansion of its higher education system only recently resulting in a slow increase in educational attainment. Third, it has a strong labour market with a low unemployment rate not only for high-skilled labour but also for medium and low-skilled jobs. This situation serves as an additional pull factor that encourages an early entry into the labour market, in particular for youth without a family background in higher education. Consequently, increasing higher education will require attracting a higher share of mature students, who are more likely to have commitments outside of higher education, such as time dedicated to work or family. This group probably needs to reconcile their various commitments with their studies, and higher education providers and policymakers should be sensitive to these needs in order to facilitate their engagement in higher education (Astin 1999; Orr 2012).

The article provides an overview of the challenges to higher education expansion and presents findings from the 2016 EUROSTUDENT student survey conducted in Malta. The article will conclude with recommendations for higher education providers and policymakers.

\section{Higher Education Expansion and Working Alongside Studies}

Increasing participation in higher education in countries that witness the 'massification' of their higher education systems is associated with reaching out and attracting a more diverse student body (Orr 2010). This expansion in Europe and 
other OECD countries is characterized by an increased participation of employed students (Auers et al. 2007; Lewis et al. 2007; Callender 2008; Hall 2010; Lowe and Gayle 2016; Mercer et al. 2016; Billett et al. 2016; Sanchez-Gelabert et al. 2017). Research in the domain of student employment and learning demonstrates not only an increasing prevalence of students involved in paid work during their studies but also that the number of hours dedicated to employment is increasing (Beerkens et al. 2011; Logan et al. 2016).

The increased prevalence of students working alongside their studies raises concerns about its impact on their academic achievement since a large body of research suggests that paid work alongside studies negatively affects academic achievement by reducing the amount of time available for studies (Svanum and Bigatti 2006; Auers et al. 2007; Callender 2008; Miller et al. 2008; Torres et al. 2010; Richardson et al. 2014; Logan et al. 2016; Mercer et al. 2016; Burston 2017; Sanchez-Gelabert et al. 2017). Moreover, research suggests that working alongside studies negatively affects the quality of the student's educational experience (Lederer et al. 2015; Lowe and Gayle 2016), stress levels and mental health (Miller et al. 2008), increases the time to degree (Tur-Sinai et al. 2017) and the likelihood of dropping out (Bozick 2007; Torres et al. 2010; Moulin et al. 2013; Hovdhaugen 2015).

However, several studies also found that working alongside studies had a limited impact on students' academic performance (Wang et al. 2010; Beerkens et al. 2011; Roshchin and Rudakov 2017) and, in some cases, even had a positive impact (Kouliavtsev 2013). Body et al. (2014) found that the impact of students' work on their academic achievement depends on their work intensity and the flexibility of their job. Similarly, Tuononen et al. (2016) suggest that students' organisational skills are also an important factor determining study progress and the impact of work on their studies. Moreover, Sanchez-Gelabert et al. (2017) found that working alongside studies had a positive impact on the transition into the labour market, especially for students whose work was related to their studies. In addition, some studies also suggest (e.g. Hall 2010) that work related to one's studies strengthens students' goal orientation.

Given that the main reason for working alongside studies is a lack of financial resources (Auers et al. 2007; Lewis et al. 2007; Hall 2010) rather than to gain work experience (Hall 2010) and since it mainly affects disadvantaged and underrepresented students in higher education (Callender 2008; Sanchez-Gelabert et al. 2017), research has stressed the need for policymakers and higher education providers to ensure a flexible provision of higher education to better support this vulnerable group of students (Hall 2010; Lowe and Gayle 2016). This would also contribute to making higher education more responsive to labour market needs by enabling those already in employment to return to higher education and undertake studies that could contribute to their career progress without the need to interrupt their employment (Beerkens et al. 2011). 


\section{Challenges to Higher Education Expansion in Malta}

The challenges to higher education expansion in Malta are specific due to the country's prolonged economic dependence on its former colony after gaining independence in 1964. This dependence was evident until 1990 and included a low-paid and low-skilled export-driven manufacturing sector (Vella 1994), which influenced higher education until the beginning of the new millennium.

This influence is evident through the higher education attainment levels in 2016 of different age groups of the population (see Fig. 1), which confirm that in previous decades participation in higher education was very limited and available only to a small share of the population. The same figure also indicates that the increase in higher education attainment in the past three decades was more considerable in Malta compared to the average of the EU 28, most notably among females, who show considerably higher rates of attainment than males.

Similarly, numerous studies including the EUROSTUDENT V survey (Hauschildt et al. 2015, p. 53), which indicates that the share of students with lower educational backgrounds is high in Malta compared to other European countries, have to be interpreted as a result of the continued overall high share of the population with a relatively low level of education.

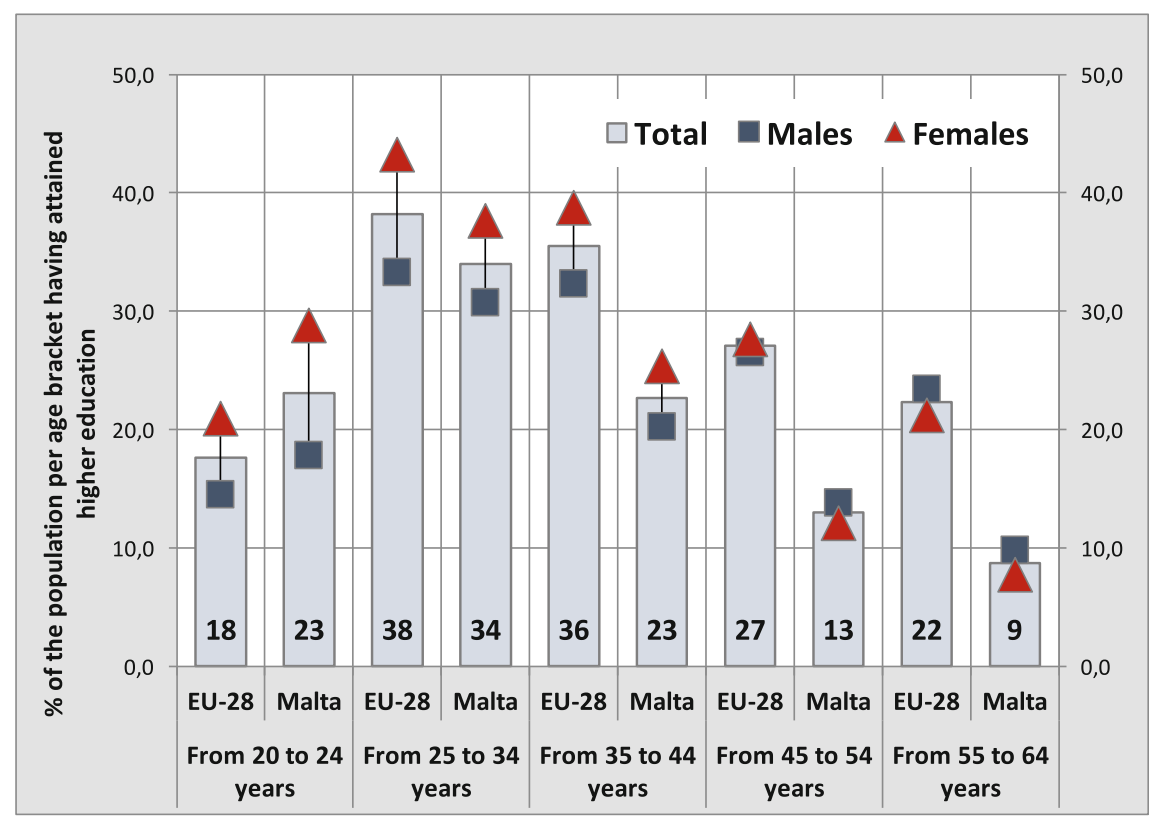

Fig. 1 Higher Education attainment rate in Malta and the EU-28 in 2016 by age group. Source EUROSTAT, edat_lfse_03 
EUROSTUDENT data for Malta also shows that students from families with a higher educational background are overrepresented in higher education in Malta in contrast to students whose parents have attained compulsory or upper secondary education, who are underrepresented in higher education (see Fig. 2).

This persistent underrepresentation of students from families with lower education attainment is of concern in view of the link between education attainment and labour market outcomes, since EUROSTAT data shows that higher levels of education are linked with higher income (see Fig. 3).

The continued expansion of the higher education sector in Malta is expected to further increase higher education attainment and the participation of underrepresented groups. However, despite a rapid increase in the higher education attainment rate among 30-34-year-olds in Malta from 17.6\% in 2005 to 29.8\% in 2016, this progress is still well below the average EU-28 rate which increased from 28.1 to $39.1 \%$ over the same period (see Fig. 4). In view of this development, Malta has set itself the target to increase higher education attainment among 30-34-year-olds to $33 \%$ by 2020 (NCFHE 2015) compared to the overarching EU 2020 target of $40 \%$ by 2020 (European Commission 2010). This target appears to be realistic if higher education participation and attainment levels continue to increase as witnessed in the past decade.

The presented data indicates that further efforts are required to increase the share of students who continue their studies at post-secondary level following compulsory education in order to increase the share of those eligible to enter higher education. Data on early school leaving in Malta (see Fig. 5) shows a sharp decrease from $33.0 \%$ in 2005 to $19.6 \%$ in 2016 . However, this rate is still considerably above the average in the EU 28 which decreased from 15.7 to $10.7 \%$

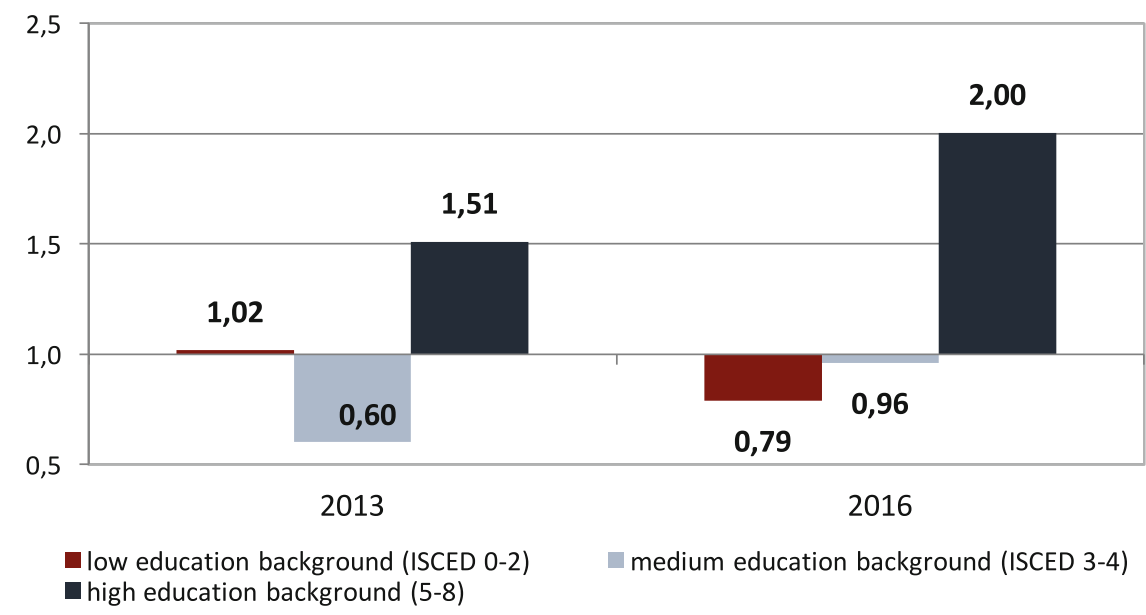

Fig. 2 Representation of students from high, medium and low educational backgrounds (based on fathers' educational attainment). Source EUROSTUDENT V national data for Malta, 2013 and EUROSTUDENT VI national data for Malta, 2016 


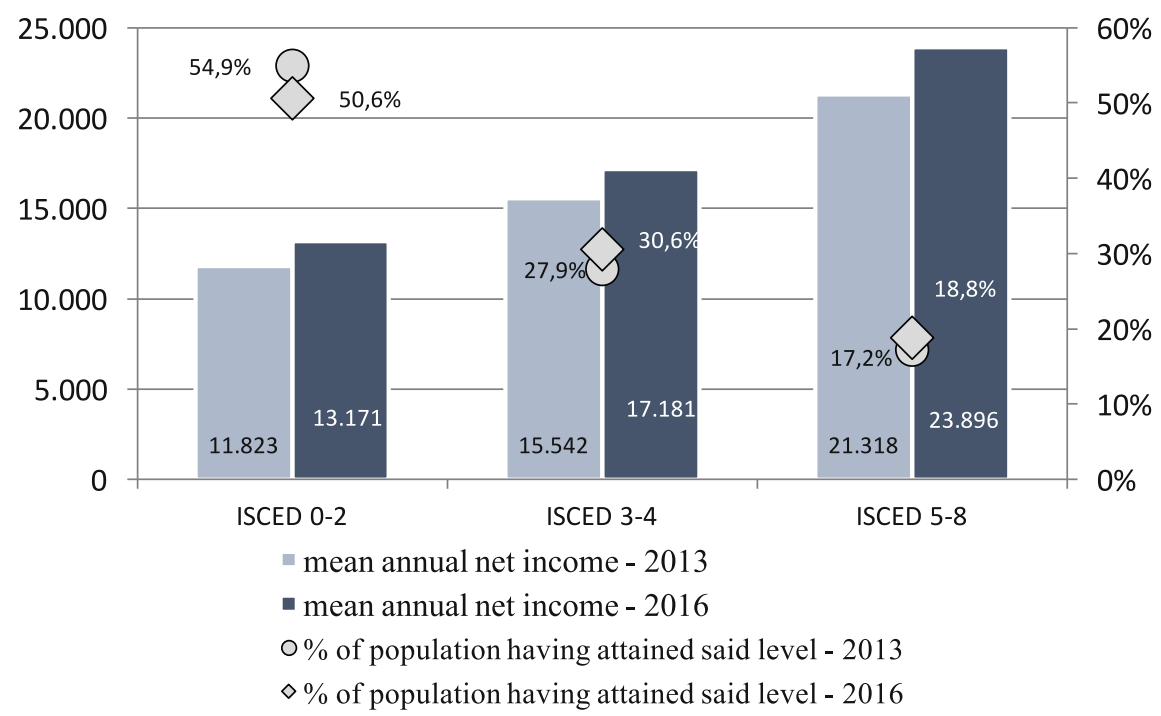

Fig. 3 Attainment rate and mean annual net income by education level attained, Malta in 2013 and 2016. Source EUROSTAT (2016), ilc_di08

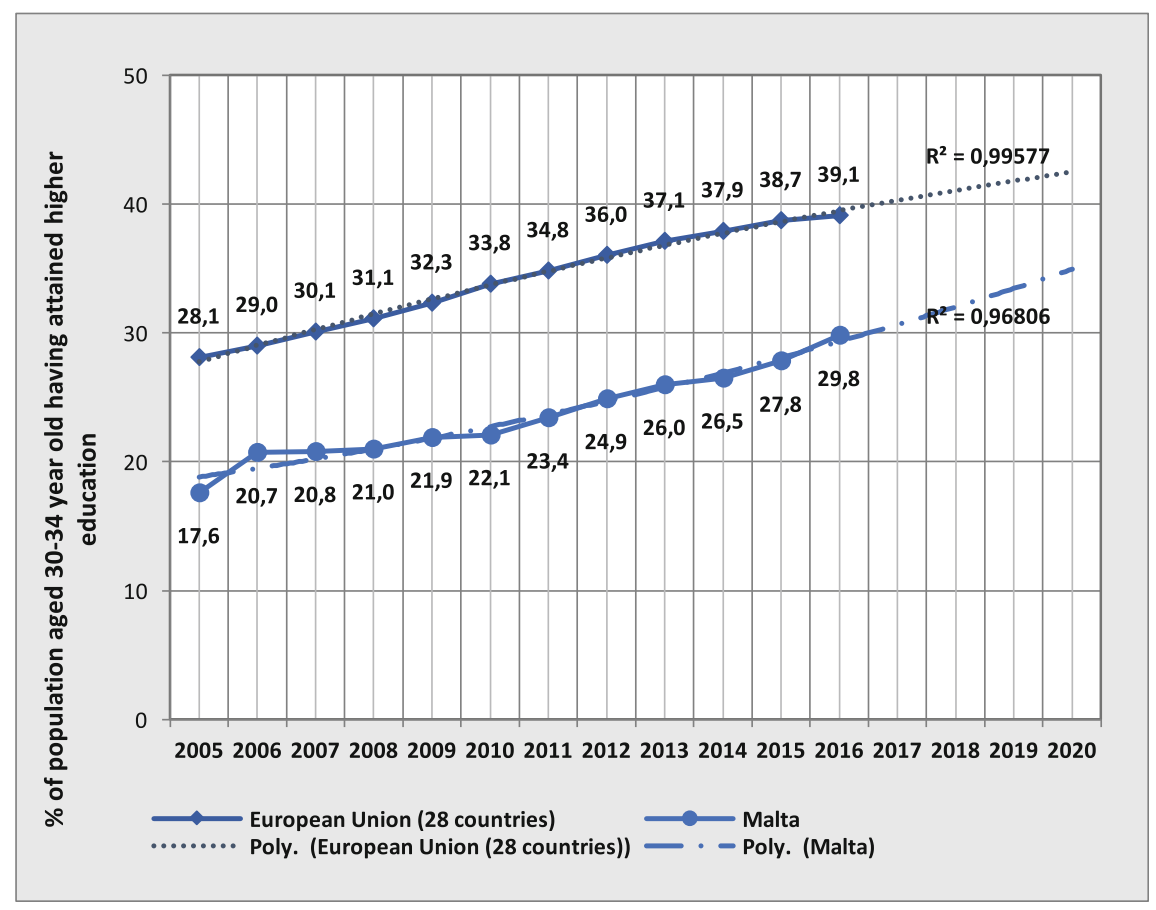

Fig. 4 Higher education attainment rate among 30-34-year-olds in Malta and EU-28. Source EUROSTAT (2016), edat_lfse_03 


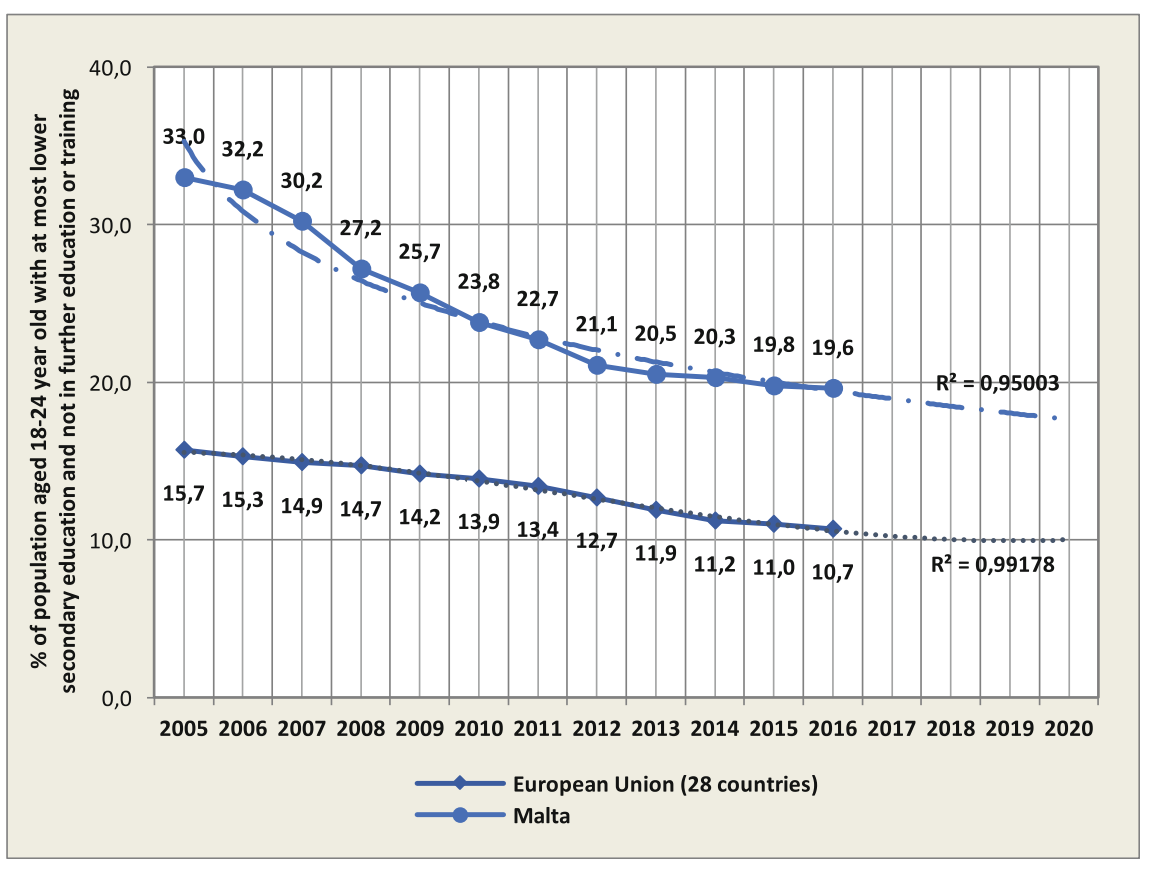

Fig. 5 Early leavers from education and training among 18-24-year-olds in Malta and EU-28. Source EUROSTAT (2016), edat_lfse_14

during the same period. If this development continues as is indicated by the trendline, it appears very unlikely that Malta will succeed to achieve the EU 2020 target of reducing the incidence of early school leaving to $10 \%$ by 2020 .

It appears that a strong labour market and a low unemployment rate in Malta are strong pull factors for an early entry into the labour market. As can be seen from EUROSTAT data, the employment rate of 15-64-year-olds in Malta has been increasing steadily in the past decade and is now just below the average of the EU 28 , while the average employment rate for the EU 28 remained rather unchanged (see Fig. 6). Moreover, over the same period, the unemployment rate in Malta decreased considerably in comparison to the average unemployment rate of the EU 28 (see Fig. 7).

This suggests that the labour market in Malta has witnessed a considerable growth when compared to other EU countries. This growth in the labour market demand in Malta appears to have been satisfied in part through an increase in the skilled labour force and in part by reintegrating unemployed workers into the labour market. However, with a currently very low unemployment rate, any future demand for skilled workers will serve as a strong pull factor for new entrants into the labour market.

This is already evident when comparing the employment rate among young people aged 15-24 in Malta and the EU 28 (see Fig. 8), whereby close to half of all 


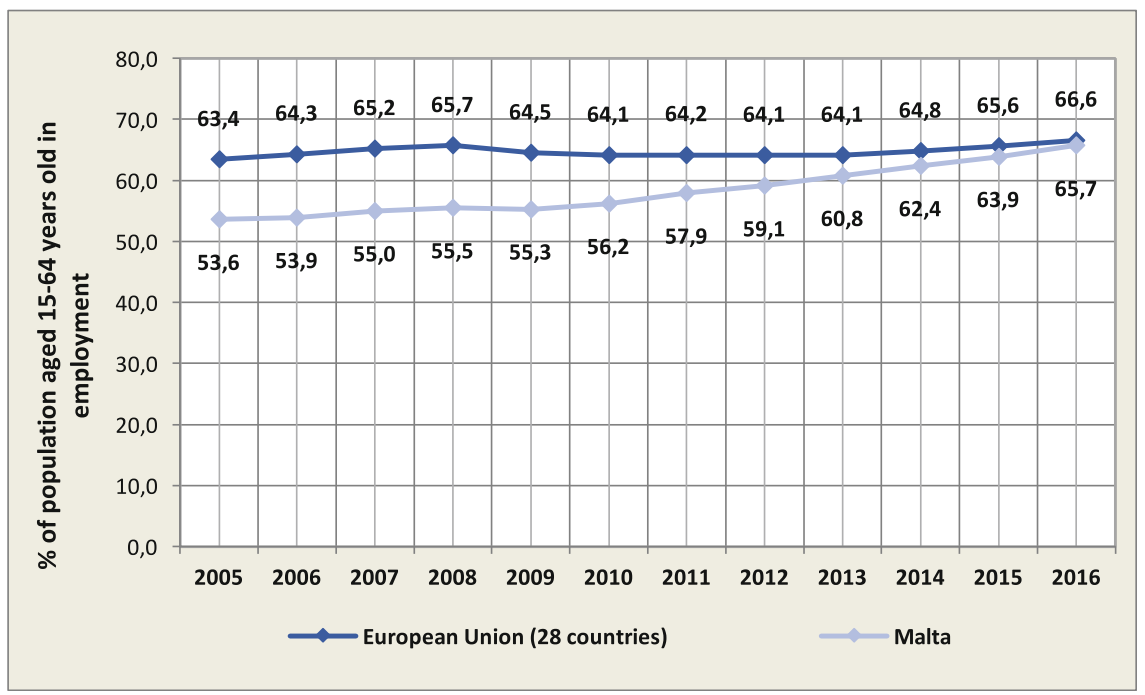

Fig. 6 Employment rate among 15-64-year-olds in Malta and the EU 28. Source EUROSTAT (2016), lfsa_ergaed

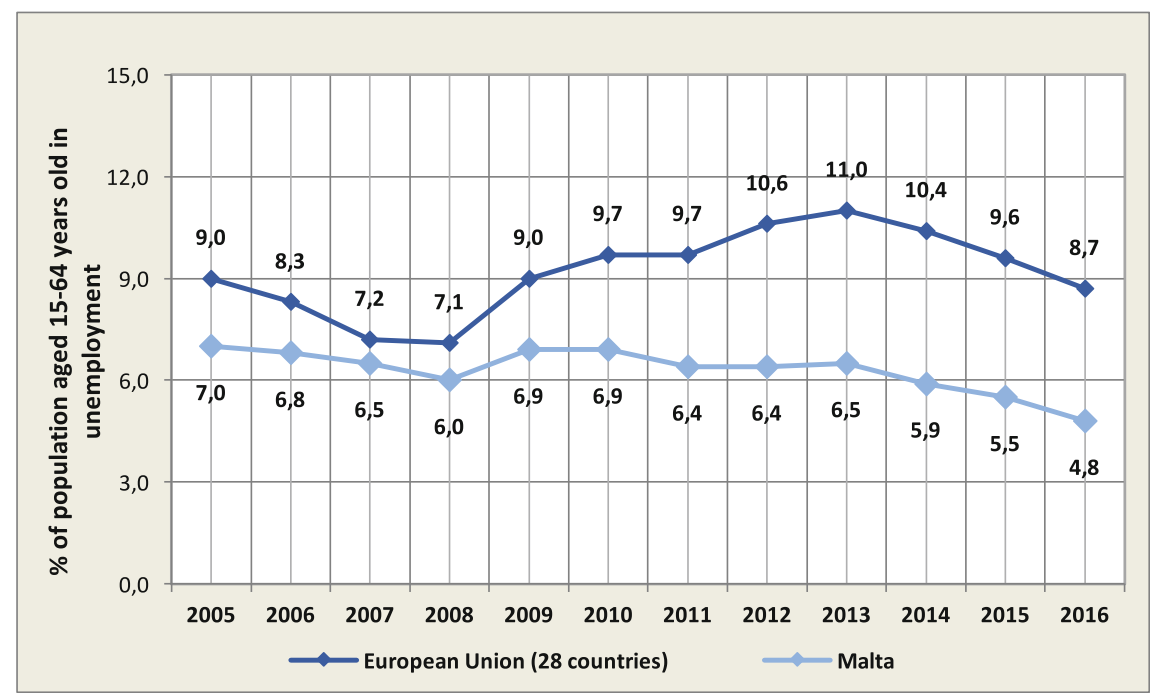

Fig. 7 Unemployment rate among 15-64-year-olds in Malta and the EU 28. Source EUROSTAT (2016), lfsa_urgaed

young people in Malta are employed compared to about one third in the EU 28. Young people in Malta are also less likely to face unemployment. While nearly one-fifth of young people aged 15-24 in the EU 28 are unemployed, the share in 


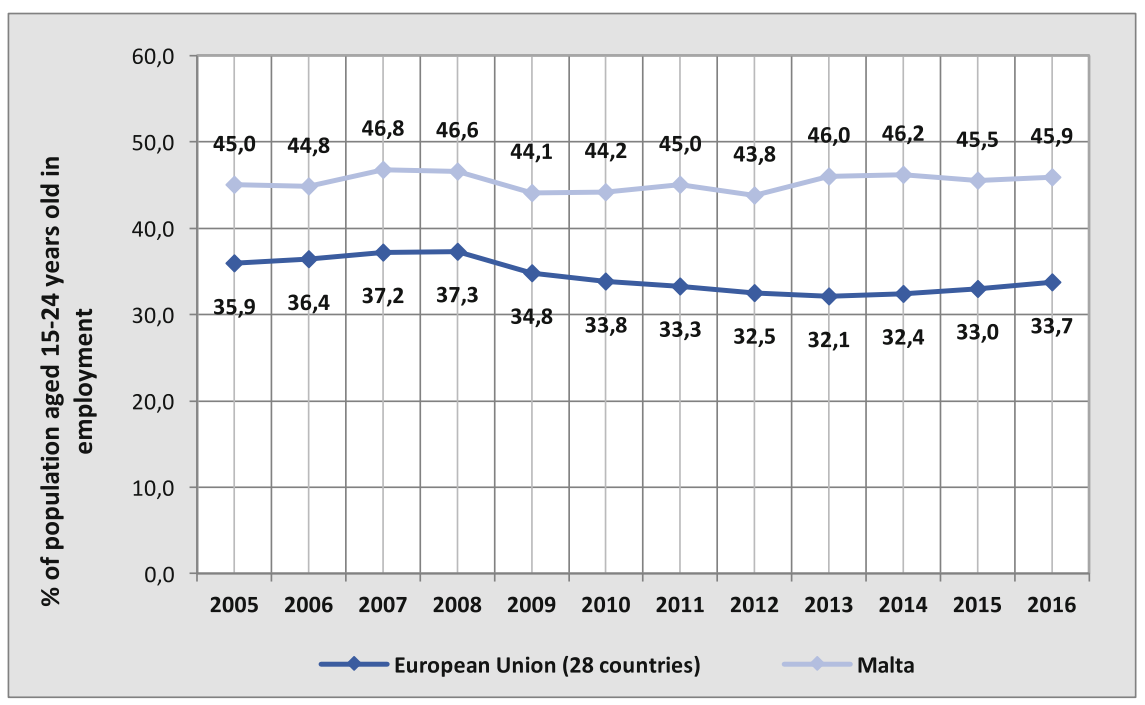

Fig. 8 Employment rate among 15-24-year-olds in Malta and the EU 28. Source EUROSTAT (2016), lfsa_ergaed

Malta in 2016 was $11.1 \%$ (see Fig. 9). Thus, a strong labour market demand with a low unemployment appears to attract many young people into employment. This is a challenge for retaining young people in education or attracting them to return to education.

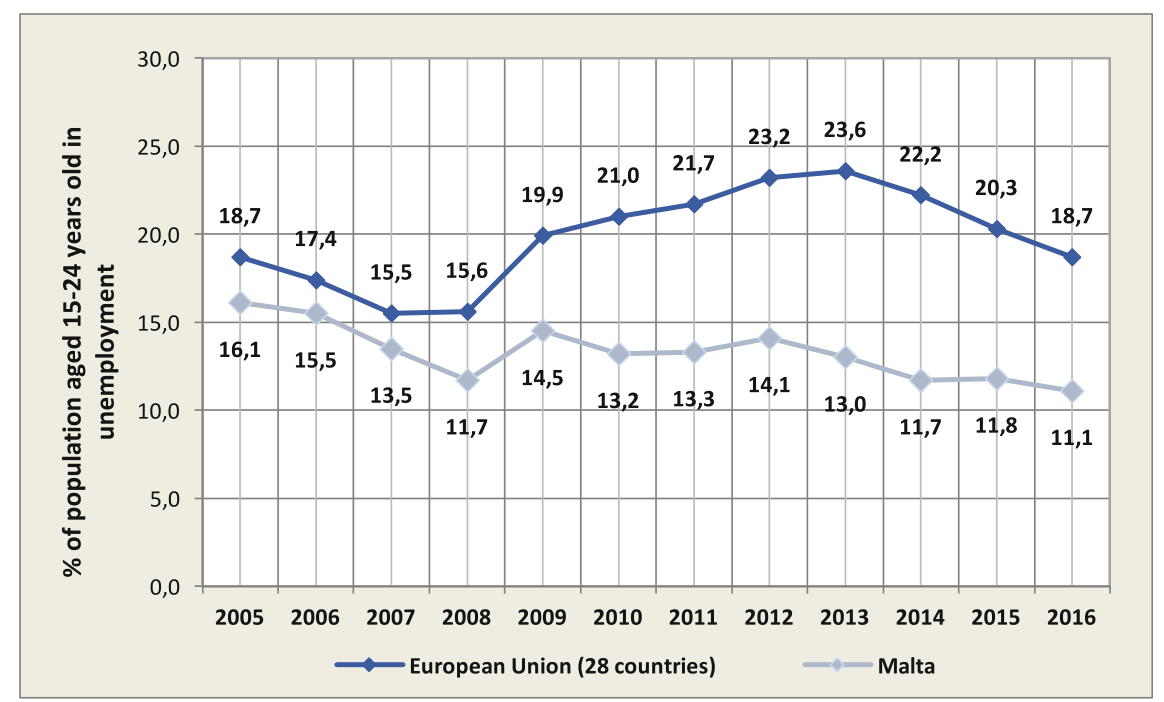

Fig. 9 Unemployment rate among 15-24-year-olds in Malta and the EU 28. Source EUROSTAT (2016), lfsa_urgaed 
Finally, our analysis of the age at entry into the labour market shows that the entry occurs as early as following the end of compulsory education between age 15 and 19 with $21.4 \%$ of this age group being employed in 2016 (see Fig. 10). However, the labour market entry is more common among youth at the ages of 20-24 and 26-29 with 66.0 and $87.6 \%$ respectively being employed. It seems, therefore, that the entry into the labour market takes place most often after completion of post-secondary education and at the first cycle of higher education.

In sum, it appears that the main challenge to higher education expansion in Malta remains the high incidence of early leaving from education, which is compounded by a strong labour market and a low unemployment rate serving as pull factors for an early entry into employment. In this scenario, the main concern of the discussion on combining work and learning in Malta might be how to encourage those who discontinued their studies to return to education in an effort to increase participation and attainment levels in higher education. This may not be achieved only through increasing the share of those entering higher education following post-secondary schooling. Since youth who entered the labour market are unlikely to return to full-time studies (Beerkens et al. 2011), they will require more flexible modes of learning. A closer look at the profile and situation of working students in Malta provides insights into the obstacles encountered by this group to provide policymakers and higher education providers with guidance on how to improve higher education provision for students combining work and learning.

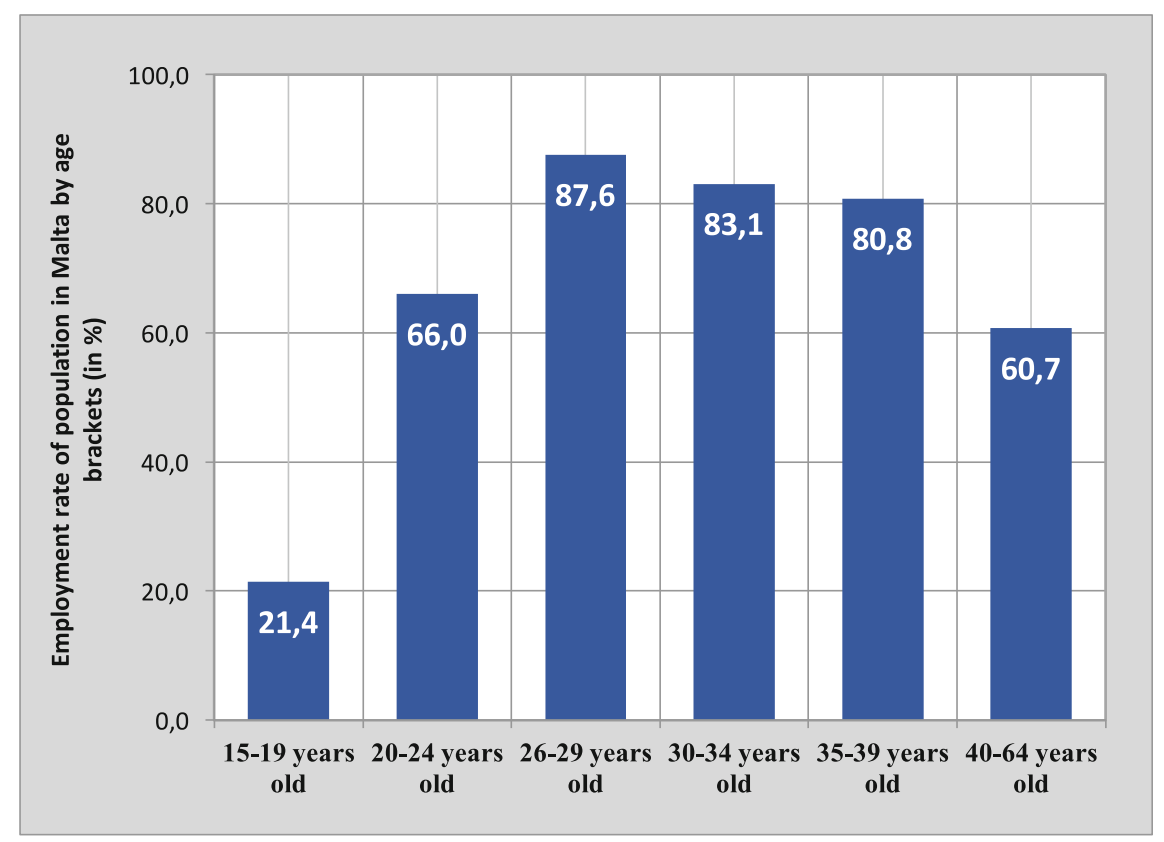

Fig. 10 Employment rate in Malta in 2016 by age bracket. Source EUROSTAT (2016), lfsa_ergaed 


\section{Working Students in Malta}

Our analysis of working students is based on the national student survey carried out in Malta in $2016(\mathrm{~N}=1,423)$ and forms part of the data collection for the EUROSTUDENT project which seeks to collect comparable data on the social and economic conditions of student life in different European countries through a common core questionnaire and common set of indicators.

Based on the findings from this survey, $52.5 \%$ of students in Malta are working alongside their studies, of which $39.0 \%$ are working regularly and $13.5 \%$ occasionally throughout the entire lecture period. Only a quarter $(26.9 \%)$ of participants in this national study reported not to work at all. This data includes both full-time and part-time students. When comparing these findings with data collected in 2013 for EUROSTUDENT V (see Fig. 11), the findings are consistent. However, one has to bear in mind that data for 2013 refers only to work during term time, excluding work during semester breaks. In $201354 \%$ of Maltese students reported to be working during term time, which compares to 52.5\% reported in 2016. The data also shows that Maltese students work more frequently than their counterparts in other countries, with the exception of students in the Netherlands.

Working alongside studies is more common among older students with $80.6 \%$ of those aged 30 years or older working regularly or occasionally compared to $40.8 \%$ of students up to 21 years of age. Also, approximately one third (31.8\%) of young

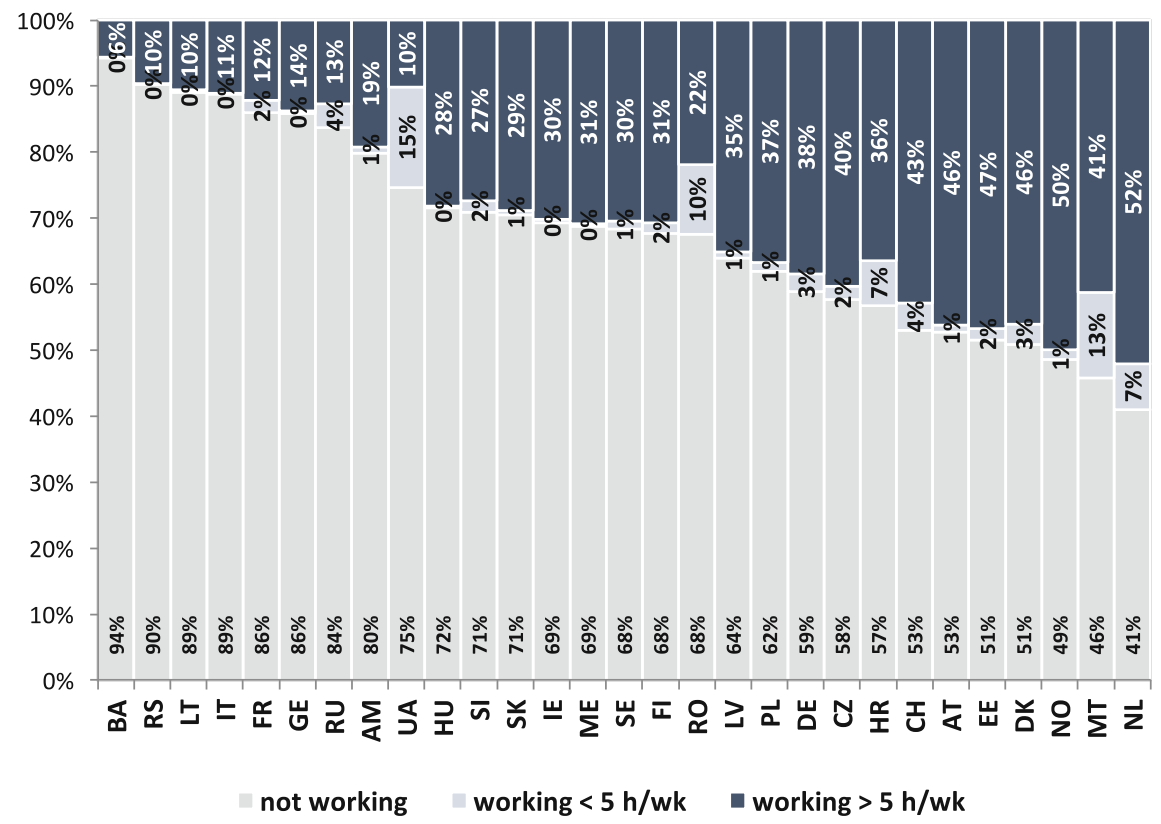

Fig. 11 Employment rate of students during term time. Source EUROSTUDENT V 
students up to the age of 21 do not work at all, while the corresponding share for students over the age of 30 is only $15.2 \%$. Students without a family background in higher education are also more likely to be working: $54.8 \%$ work during term time compared to $45.0 \%$ of those whose parents have attained higher education. This may be linked to the continued expansion of the higher education sector in Malta since students without a higher education background in their family are more likely to be older (mean age of 26.4) than those with a higher education background (mean age of 23.4) and, as shown before, older age cohorts are less likely to have benefitted from higher education. Given that higher levels of education attainment tend to be linked to higher earnings, it is not surprising that working students also tend to assess their parents' wealth more negatively than students who do not work at all. Overall, $25.5 \%$ of students who work during term time consider their parents as not very well-off compared to $14.9 \%$ of students who do not work at all. Moreover, it appears that with increasing time dedicated to work, the share of students who consider their parents less well-off is increasing, namely $20.7 \%$ of those working between 1 and 20 h per week compared to $30.7 \%$ of those working more than $20 \mathrm{~h}$ per week. Thus, the need to work more may be linked to parents' limited means to provide support to their children, suggesting that working alongside studies is linked to financial demands.

Indeed, students working alongside their studies in Malta mention most often that they do so to cover their living costs or would not be able to continue their studies without the income from their paid job (see Fig. 12). While students also value the quality of work experience gained through their paid job, this factor is of less importance compared to the income, and the difference in rating is most notable for those working more than $20 \mathrm{~h}$ per week while it is less pronounced for those working between 1 and $20 \mathrm{~h}$ per week. It is also important to note that over one third $(36.4 \%)$ of students working more than $20 \mathrm{~h}$ per week do so because they

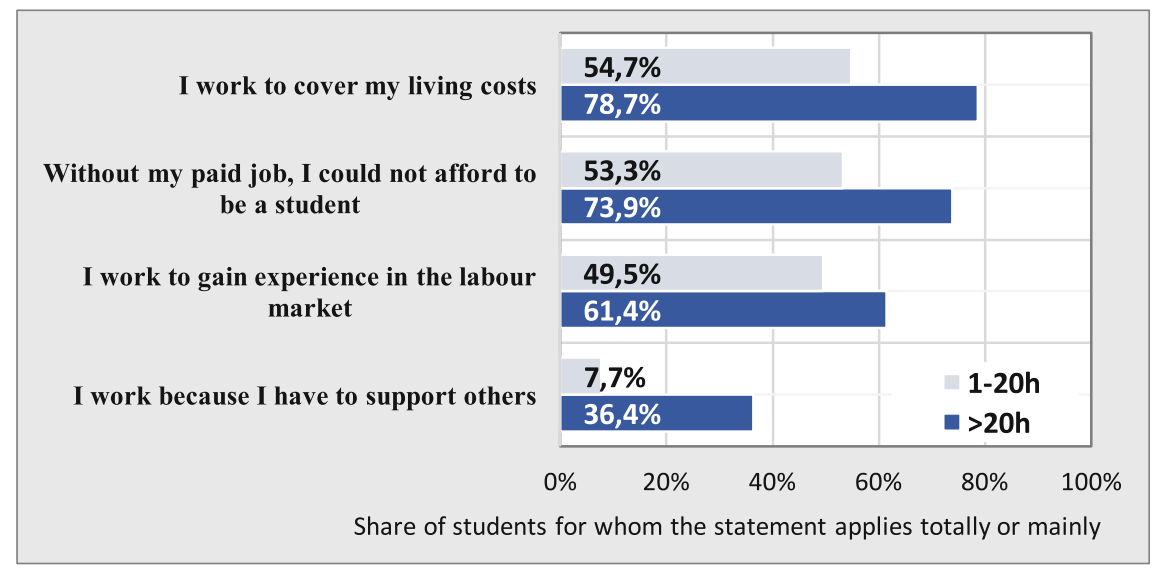

Fig. 12 Reasons for working during term time by hours per week spent in paid jobs. Source EUROSTUDENT VI national data for Malta, 2016 
need to support others. Consequently, family responsibilities are not only a potential time constraint on students, but also increase financial commitments.

Our findings are consistent with other studies that examine the relationships between work and learning indicating that students working alongside their studies are generally older (Auers et al. 2007; Beerkens et al. 2011; Hauschildt et al. 2015) and tend to be driven by financial constraints to engage in paid work alongside their studies (Callender 2008; Beerkens et al. 2011; Hauschildt et al. 2015).

When looking at the programmes followed by students combining work and learning, it appears that students enrolled in short-cycle higher education $(74.6 \%$ work) or following Master programmes (55.3\% work) are working more often than students enrolled in a Bachelor degree (46.1\% work). The results of our study indicate that combining work and learning is common both among students seeking to attain a first higher education qualification and those following postgraduate degrees. This is further corroborated by the fact that students with a delay of more than 2 years between attaining the entry qualification for higher education and eventually entering higher education are more likely to be enrolled in short-cycle programmes, namely $24.6 \%$ of them, compared to $11.5 \%$ of students who entered higher education directly after attaining the entry qualification. Students who delayed their transition into higher education are also more likely to work during their studies $(70.9 \%)$ than those who entered higher education directly after graduating from post-secondary education (48.5\%). Providing more flexible study programmes that would allow students to combine work and learning could, therefore, serve as a strategy to help individuals who have left the education system to return and continue their studies. This would contribute to increasing the share of non-traditional students in higher education as well as increase education attainment of the entire population.

Considering that research frequently links working alongside studies with lower academic achievement (Svanum and Bigatti 2006; Auers et al. 2007; Callender 2008; Miller et al. 2008; Torres et al. 2010; Richardson et al. 2014; Logan et al. 2016; Mercer et al. 2016; Burston 2017; Sanchez-Gelabert et al. 2017), increased stress levels and diminished health (Miller et al. 2008), increased time to degree (Tur-Sinai et al. 2017) and higher chances of drop-out (Bozick 2007; Torres et al. 2010; Moulin et al. 2013; Hovdhaugen 2015), further analysis of the impact of paid work on time dedicated to studies and the outcomes of work for students in Malta are necessary (see Fig. 13).

Overall, students in Malta without any work commitments spend on average $48 \mathrm{~h}$ per week on study-related activities, of which $19 \mathrm{~h}$ are dedicated to taught lessons and $29 \mathrm{~h}$ to self-study. When comparing this with data from EUROSTUDENT V, which was collected in 2013 (Hauschildt et al. 2015), it appears that students in Malta spend a considerable amount of time per week on study-related activities. In fact, the (unweighted) average time spent on study-related activities across all countries participating in EUROSTUDENT V by students who were not working was $38 \mathrm{~h}$, of which $20 \mathrm{~h}$ were dedicated to taught lessons and $18 \mathrm{~h}$ to self-study (Hauschildt et al. 2015, p. 108). In comparison to 


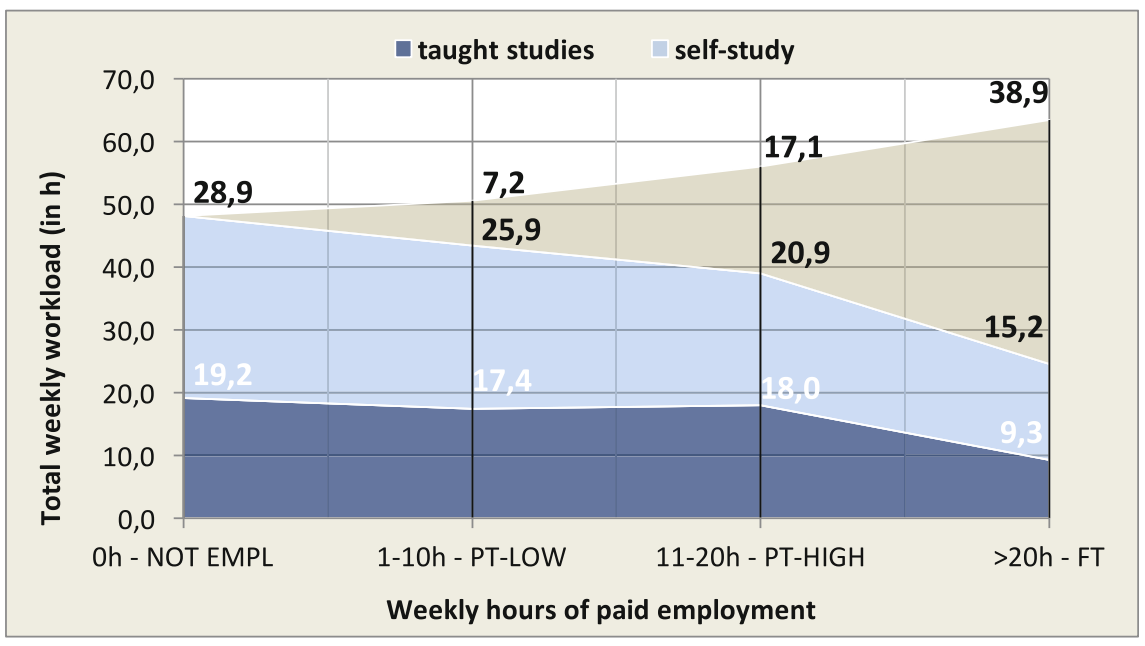

Fig. 13 Time budget of all students for study-related activities by extent of employment-Malta (in hours/week). Source EUROSTUDENT VI national data for Malta, 2016

students in other European countries, students in Malta appear to spend considerably more time on self-study.

In view of this, it is plausible that students who are working alongside their studies would compensate for the additional workload arising from their paid job first and foremost by reducing the time they spend on self-study. Indeed, the time spent on taught lessons hardly decreases for students working between 1 and $20 \mathrm{~h}$ per week compared to those students who do not work at all. This is consistent with the pattern observed across EUROSTUDENT V countries, namely that work commitments encroach on study-related activities and, first and foremost, on time spent on self-study (Hauschildt et al. 2015, p. 108).

Moreover, it is evident that students with work commitments report a higher overall weekly workload compared to students who do not work at all and their time budget increases considerably with increasing time dedicated to their paid job. While students who do not work at all have a weekly time budget of $48 \mathrm{~h}$, students working more than $20 \mathrm{~h}$ per week have an overall weekly time budget of approximately $63 \mathrm{~h}$. As a result, time spent on paid jobs does not only encroach on time dedicated to studies, but also on students' free time reducing the time available for relaxation and recreation (Astin 1999; Miller et al. 2008; Lederer et al. 2015; Mercer et al. 2016; Lowe and Gayle 2016). For students with family commitments apart from work, this may be a considerable strain.

Given the diverse needs of students and the centrality of studies in their lives, Orr (2012, p. 185) proposed a model of four constellations of organisational learning (see Fig. 14). He suggests that the programme design that is responsive to these diverse needs could be guided by this model, whereby it may be appropriate to design programmes expecting a high degree of centrality of studies for young 
Fig. 14 Four constellations of organizational learning. Source Orr (2012: 185)

\section{Flexibility of institutional provision: high}

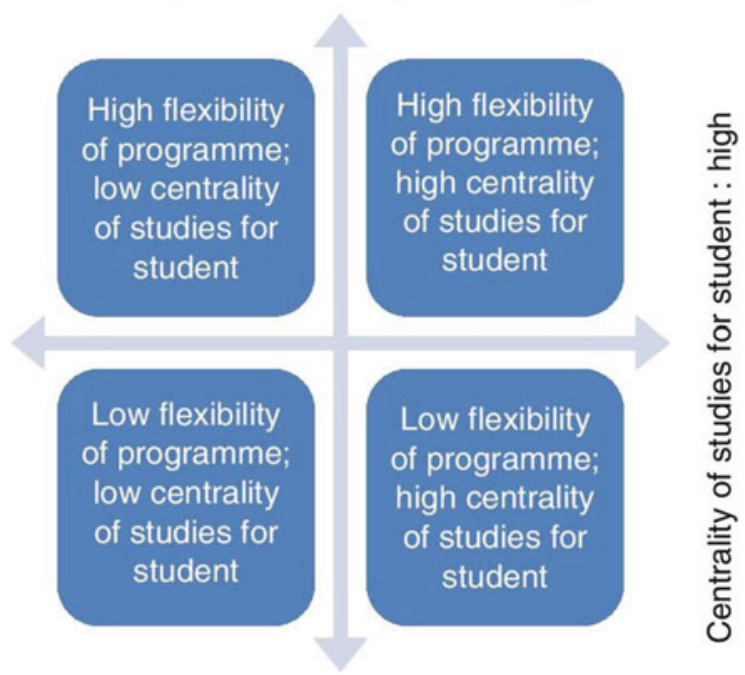

students, but this may be less appropriate for mature students that may have to reconcile studying with other commitments, such as work or family life. This is in line with recommendations arising from the research of Perna (2010), Hall (2010) and Lowe and Gayle (2016). Besides the need for flexible forms of programme delivery, research also suggests that learning styles of mature students differ from those of traditional students (Morton 1963; Richardson 1995; Toynton 2005) by benefitting from the recognition and utilisation of their prior experience and multidisciplinary approaches to learning. This means that higher education institutions need to be sensitive to these needs and accommodate them in their teaching methods in order to adequately support mature students.

The analysis of the study-related workload of students working more than $20 \mathrm{~h}$ per week shows that it is about half ( $24.5 \mathrm{~h}$ per week) of the study-related workload reported by those students not working at all. This suggests that those working more than $20 \mathrm{~h}$ per week are more often enrolled in part-time programmes, which in Malta generally correspond to half of the weekly workload of a full-time programme. Indeed, working alongside studies appears to be the norm among students following their programme on a part-time basis $(93.3 \%)$, while those studying full-time work considerably less often $(42.2 \%)$. In addition, the former are most often in regular employment $(91.9 \%)$ rather than working only occasionally during the lecture period (1.4\%). This suggests that students working alongside their studies seek programmes providing them with more flexibility to combine their work commitments with their studies, which supports Orr's model (2012) arguing for more flexible forms of learning for students with a low centrality of studies in their lives. 
It is also evident that employment is more common among students enrolled in non-university type institutions (67.5\% work) than in universities (48.6\% work). This could point to non-university institutions providing easier access to higher education for working students or possibly more flexible or less workload intensive study programmes. This is further corroborated by a much smaller share of non-university students spending more than $40 \mathrm{~h}$ per week on study-related activities (39\%) compared to students at universities (49\%) despite the fact that there is little difference in the share of students enrolled in full-time programmes at universities (80\%) and non-university institutions (78\%). Further analysis also shows that students enrolled in non-university institutions are more likely to have parents that did not attain higher education (78\%) than students enrolled at universities (58\%). This clearly indicates that non-university institutions are more easily accessible to non-traditional students.

The impact of work on students' overall workload and the resulting strategies for enrolment in more flexible study programmes raise the question of the extent to which such strategies are successful in terms of raising the quality of their educational experience (Lederer et al. 2015; Lowe and Gayle 2016) or having a positive impact on their stress levels and health (Miller et al. 2008). This may be reflected in students' satisfaction with their time-budget for study-related activities and paid jobs (see Fig. 15). It appears that those students who are working more would like to dedicate more of their time to study-related activities and less to paid jobs. This suggests an additional opportunity for improvement of the educational experience of working students by providing them with more flexible opportunities for combining work and studies. It appears that more flexibility may be needed

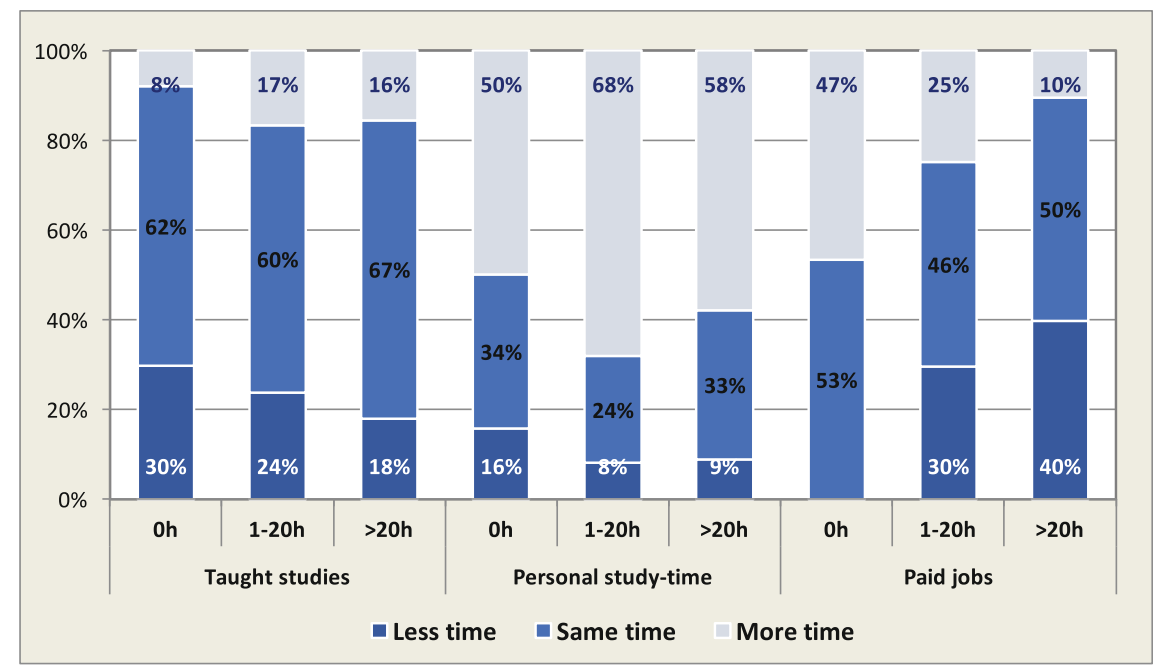

Fig. 15 Students' satisfaction with time spent on taught studies, personal study time and paid jobs by extent of employment. Source EUROSTUDENT VI national data for Malta, 2016 
from employers to release staff engaged in education. Given the importance of working for financing living costs, such initiatives should not result in loss of earnings. Government incentives may help in this regard and may provide positive impulses for both employees and employers to encourage further studies alongside work that could be beneficial for both parties while contributing to an overall increase in education attainment. Research on employers' perceptions of the attractiveness and effectiveness of such measures as well as on existing initiatives undertaken by employers and governments to promote further education of their employees may prove useful in this regard.

It is also interesting to note that working students overwhelmingly wish to spend more time on personal studies rather than taught lessons. Indeed, since time for personal studies is reduced first in order to compensate for additional workload arising from paid jobs, this response is consistent. This desire to increase their personal study time rather than taught lessons underscores the need for more flexible forms of learning for those students with commitments apart from studies since an increase in taught lessons may cause conflict with their work schedule or family commitments (Orr 2012).

Apart from the negative impact of an increased overall weekly workload on students' academic progress, research indicates that combining work and learning has a more detrimental effect on academic success if the students' job is not related to their studies (Sanchez-Gelabert et al. 2017). The link between job and studies is also important since research revealed that the transition into the labour market is improved if students work in jobs that are related to their studies (Sanchez-Gelabert et al. 2017). Such a close link between job and studies could contribute to contextualise what is being learned and, in this way, increase the relevance of higher education to the labour market. Indeed, linking higher education more closely with the needs of the labour market has also been highlighted by the New Skills Agenda of the European Commission (European Commission 2016). Given that in Malta combining work and learning is particularly common among mature students seeking to attain a first higher education qualification and those with a delayed entry into higher education, it is worthwhile exploring whether these generally underrepresented and vulnerable groups of students hold jobs that are related to their studies.

In view of this, it is positive to note that the data indicates that those most likely to be negatively affected in their studies by their extensive job-related workload hold more often jobs related to their studies (see Fig. 16). Most students working more than $20 \mathrm{~h}$ per week hold a job that is (very) closely related to their studies $(65.1 \%)$, while only $30.0 \%$ of students working $1-20 \mathrm{~h}$ per week have a job that is closely related to their studies. Moreover, most students enrolled in short-cycle or Master programmes hold jobs that are closely related to their studies (63.9 and $60.6 \%$ respectively). Consistent with the previous finding that students with a more intensive job-related workload are more often enrolled part-time, our results also indicate that students with a study-related workload of up to $20 \mathrm{~h}$ per week, which is consistent with a part-time programme, are more often in jobs related to their studies compared to students following programmes with a higher study-related weekly workload. 


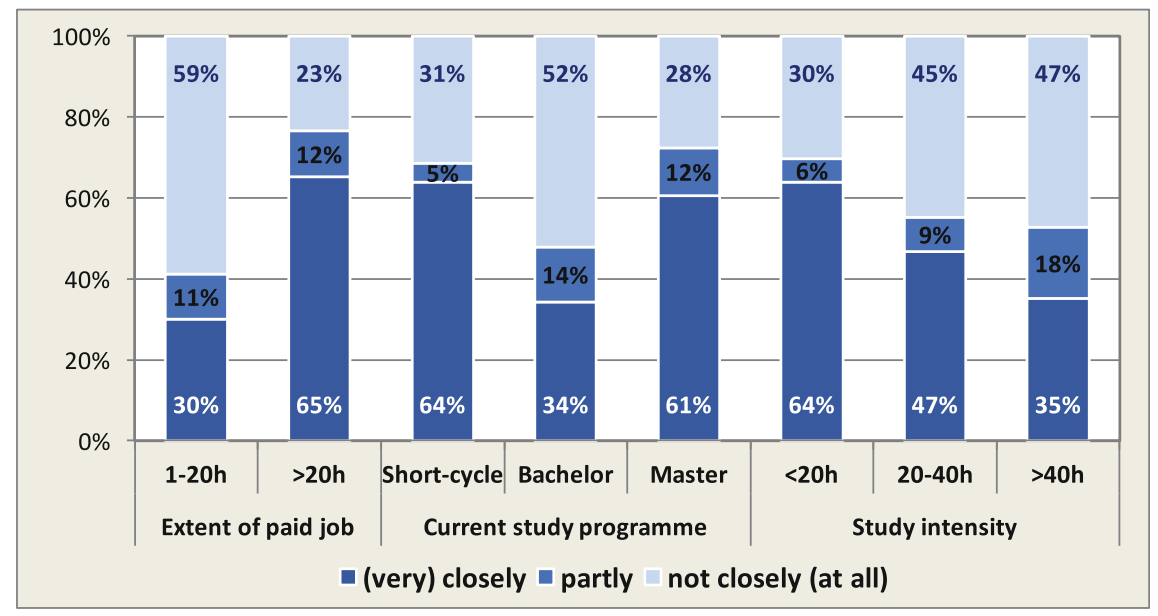

Fig. 16 Link between studies and job of students working throughout the lecture period. Source EUROSTUDENT VI national data for Malta, 2016

Despite the increased burden arising from combining extensive work commitments with their studies, students working more than $20 \mathrm{~h}$ per week and those enrolled in short-cycle or Master programmes have more often jobs that are related to their studies. This would allow them to contextualise what they are learning in their workplace or explore aspects of their work more deeply through their studies. This clearly contributes to the policy objective of making higher education more responsive to the needs of the labour market (European Commission 2016). Given that students undertaking short-cycle or Master programmes appear to have been employed before taking up their studies, the link between studies and job may be the result of students choosing programmes aimed at furthering their career development. This appears to indicate that it is likely that combining work and learning in Malta may be a springboard to increase both one's level of education as well as improve labour market chances. From a policy point of view, this finding is positive since combining work and learning delivers both on making higher education more inclusive by increasing attainment levels as well as on making higher education more responsive to labour market needs.

\section{Conclusions and Recommendations}

Overall, EUROSTUDENT VI data for Malta are consistent with other research on work and learning indicating that working students in Malta are usually older, from families without a higher education background and with limited financial resources. As a result, students work most often because of financial necessity, in particular, if they have to support other family members. Students working more 
than $20 \mathrm{~h}$ per week alongside their studies have a considerably high workload resulting from their paid job and their studies and that is despite the fact that they seek more often part-time study programmes offering them more flexibility in terms of combining work and learning.

The fact that combining work and learning is more frequent among those undertaking short-cycle programmes and those with a delayed entry into higher education suggests that the provision of flexible study programmes which allow for combining studies and work could encourage those who have left the education system to return and continue their studies. From this perspective, combining work and learning appears to be a springboard to increase the share of non-traditional students in higher education and also contribute to increasing educational attainment in Malta. In this context, it is encouraging to note that this underrepresented group of students is often enrolled in programmes of study related to their job. Therefore, despite the increased workload arising from working alongside studies, this close link can help work and learning and positively contribute to long-term labour market outcomes.

Research also shows that working students need more time for their studies, in particular time for personal studies, which sharply decreases with increased work intensity. At the same time, a considerable share of students working more than $20 \mathrm{~h}$ per week expresses the desire to reduce the weekly workload associated with their paid job. Since financial constraints are the main reason for combining work and learning, such decrease of work-related hours is most likely an option only if it does not result in loss of income. This suggests that strategies to facilitate combining work and learning should focus on both increasing the flexibility of study programmes and encouraging employers to support their employees who are seeking to further their studies. The support could come in the form of a variety of measures, including paid study leave or sabbaticals. Financial incentives by government to this end may be useful, apart from support for students with financial needs. This support is particularly valuable in view of the high incidence of working students undertaking studies that are related to their job. Thus, their involvement in higher education contributes to increasing educational attainment, productivity and improves the quality of work.

\section{References}

Astin, A. W. (1999). Student involvement: A developmental theory for higher education. Journal of College Student Development, 40(5), 518-529.

Auers, D., et al. (2007). Flipping burgers or flipping pages? Student employment and academic attainment in post-Soviet Latvia. Communist and Post-Communist Studies, 40, 477-491.

Beerkens, M., et al. (2011). University studies as a side job: Causes and consequences of massive student employment in Estonia. Higher Education, 61, 679-692.

Bergan, S. (2005). Higher education as a "public good and public responsibility": What does it mean? In S. Bergan \& L. Weber (Eds.), The public responsibility for higher education and research (pp. 13-28). Strasbourg: Council of Europe Publishing. 
Billett, S., et al. (2016). Augmenting higher education students' work experiences: Preferred purposes and processes. Studies in Higher Education (3 November 2016). https://doi.org/10. 1080/03075079.2016.1250073.

Body, K. M.-D., et al. (2014). Does student employment really impact academic achievement? The case of France. Applied Economics, 46(25), 3061-3073.

Bozick, R. (2007). Making it through the first year of college: The role of students' economic resources, employment, and living arrangements. Sociology of Education, 80, 261-284.

Brooks, R. (2017). Understanding the higher education student in Europe: A comparative analysis. Compare (8 May 2017). https://doi.org/10.1080/03057925.2017.1318047.

Burston, M. A. (2017). I work and don't have time for that theory stuff: Time poverty and higher education. Journal of Further and Higher Education, 41(4), 516-529.

Callender, C. (2008). The impact of term-time employment on higher education students' academic attainment and achievement. Journal of Education Policy, 23(4), 359-377.

European Commission. (2010, March 3). Communication from the commission. Europe 2020. A strategy for smart, sustainable and inclusive growth.

European Commission. (2016, June 10). A new skills agenda for Europe: Working together to strengthen human capital, employability and competitiveness.

European Council. (2000, March 23 and 24). Presidency conclusions. Lisbon European Council.

EUROSTAT. (2016). Retrieved from http://appsso.eurostat.ec.europa.eu.

EUROSTUDENT V. (2012-2015). Retrieved from http://database.eurostudent.eu/es5/.

EUROSTUDENT VI. (2016-2018). Retrieved from http://database.eurostudent.eu/es6/public/\#.

Hall, R. (2010). The work-study relationship: Experiences of full-time university students undertaking part-time employment. Journal of Education and Work, 23(5), 439-449.

Hauschildt, K., Gwosć, C., Netz, N., \& Mishra, S. (2015). Social and economic conditions of student life in Europe. Synopsis of indicators. EUROSTUDENT V 2012-2015. Bielefeld: W. Bertelsmann Verlag GmbH \& Co. KG.

Hovdhaugen, E. (2015). Working while studying: The impact of term-time employment on dropout rates. Journal of Education and Work, 28(6), 631-651.

Kouliavtsev, M. (2013). 'The impact of employment and extracurricular involvement on undergraduates' performance in a business statistics course. Journal of Economics and Economic Education Research, 14(3), 53-66.

Lederer, A. M., Autry, D. M., Day, C. R., \& Oswalt, S. B. (2015). The impact of work and volunteer hours on the health of undergraduate students. Journal of American College Health, 63(6), 403-408.

Lewis, C., Dickson-Swift, V., Talbot, L., \& Snow, P. (2007). Regional tertiary students and living away from home: A priceless experience that costs too much? Australian Journal of Social Issues, 42(4), 531-547.

Logan, J., Hughes, T., \& Logan, B. (2016). Overworked? An observation of the relationship between student employment and academic performance. Journal of College Student Retention: Research, Theory and Practice, 18(3), 250-262.

London Communiqué. (2007, May 18). Towards the European higher education area: Responding to challenges in a globalised world.

Lowe, J., \& Gayle, V. (2016). From lifelong learning to youth employment: Back to the future for higher education in Scotland's colleges. Journal of Further and Higher Education, 40(3), 351-371.

Mercer, J., Clay, J., \& Etheridge, L. (2016). Experiencing term-time employment as a non-traditional aged university student: A Welsh study. Research in Post-Compulsory Education, 21(3), 181-195.

Miller, K., Danner, F., \& Staten, R. (2008). Relationship of work hours with selected health behaviors and academic progress among a college student cohort. Journal of American College Health, 56(6), 675-679.

Morton, R. K. (1963). Teaching mature students. Improving College and University Teaching, 11 (2), 84-86. 
Moulin, S., Doray, P., Laplante, B., \& Street, M. C. (2013). Work intensity and non-completion of university: Longitudinal approach and causal inference. Journal of Education and Work, 26(3), 333-356.

National Commission for Further and Higher Education. (2015). Higher education strategy for Malta within the context of the further and higher education strategy 2020 (NCHE, 2009) and the framework for the education strategy for Malta 2015-2024.

Orr, D. (2010). Integrating an aging student population into higher education-Challenges for evidence-based policy in Europe. Canadian Journal of Higher Education Revue canadienne d'enseignment superieure, 40(3), 25-42.

Orr, D. (2012). Widening access to higher education-What can EUROSTUDENT say about the new challenges emerging for teaching and learning. In A. Curaj, P. Scott, L. Vlasceanu, \& L. Wilson (Eds.), European higher education at the crossroads. Between the Bologna process and national reforms. Part 1 (pp. 173-190). Dordrecht, Heidelberg, New York, London: Springer.

Perna, L. W. (Ed.). (2010). Understanding the working college student. New research and its implications for policy and practice. Sterling: Stylus Publishing LLC.

Richardson, J. T. E. (1995). Mature students in higher education: II. An investigation of approaches to studying and academic performance. Studies in Higher Education, 20(1), 5-17.

Richardson, M., Evans, C., \& Gbadamosi, G. (2014). The work-study nexus: The challenges of balancing full-time business degree study with a part-time job. Research in Post-Compulsory Education, 19(3), 302-309.

Roshchin, S., \& Rudakov, V. (2017). Patterns of student employment in Russia. Journal of Education and Work, 30(3), 314-338.

Sanchez-Gelabert, A., Figueroa, M., \& Elias, M. (2017). Working whilst studying in higher education: The impact of the economic crisis on academic and labour market success. European Journal of Education, 52, 232-245.

Svanum, S., \& Bigatti, S. M. (2006). The influences of course effort and outside activities on grades in a college course. Journal of College Student Development, 47(5), 564-576.

Torres, V., Gross, J. P. K., \& Dadashova, A. (2010). Traditional-age students becoming at-risk: Does working threaten college students' academic success? Journal of College Student Retention: Research, Theory and Practice, 12(1), 51-68.

Toynton, R. (2005). Degrees of disciplinarity in equipping mature students in higher education for engagement and success in lifelong learning. Active Learning in Higher Education, 6(2), $106-117$.

Tuononen, T., Parpala, A., \& Mattsson, M. (2016). Work experience in relation to study pace and thesis grade: Investigating the mediating role of student learning. Higher Education, 27(1), $41-58$.

Tur-Sinai, A., Romanov, D., \& Zussman, N. (2017). The true effect of students' employment on the duration of studies. Applied Economics, 49(33), 3328-3340.

Vella, M. (1994). That favourite dream of the colonies': Industrialisation, dependence and the limits of development discourse in Malta. In R. G. Sultana \& G. Baldacchino (Eds.), Maltese society: A sociological inquiry (Vol. 55-78). Malta: Mireva Publications.

Wang, H., Kong, M., Shan, W., \& Vong, S. K. (2010). The effects of doing part-time jobs on college student academic performance and social life in a Chinese society. Journal of Education and Work, 23(1), 79-94.

Zgaga, P. (2005). Higher education for a democratic culture-The public responsibility. In S. Bergan \& L. Weber (Eds.), The public responsibility for higher education and research (pp. 107-116). Strasbourg: Council of Europe Publishing. 
Open Access This chapter is licensed under the terms of the Creative Commons Attribution 4.0 International License (http://creativecommons.org/licenses/by/4.0/), which permits use, sharing, adaptation, distribution and reproduction in any medium or format, as long as you give appropriate credit to the original author(s) and the source, provide a link to the Creative Commons license and indicate if changes were made.

The images or other third party material in this chapter are included in the chapter's Creative Commons license, unless indicated otherwise in a credit line to the material. If material is not included in the chapter's Creative Commons license and your intended use is not permitted by statutory regulation or exceeds the permitted use, you will need to obtain permission directly from the copyright holder.

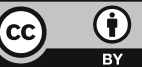

